\title{
ANALISIS SISTEM AKUNTANSI PENGGAJIAN DALAM RANGKA MENINGKATKAN PENGENDALIAN INTERN PADA PT. SARANA SULUT VENTURA
}

\author{
Jeni Jones $^{1}$, Herman Karamoy ${ }^{2}$, Sonny Pangerapan ${ }^{2}$ \\ 1,2 Jurusan Akuntansi, Fakultas Ekonomi dan Bisnis, Universitas Sam Ratulangi, Jl. Kampus Bahu, Manado, \\ 95115, Indonesia \\ ${ }^{1}$ E-mail: jenni.jo22@yahoo.co.id
}

\begin{abstract}
Payroll accounting system is a group of human resources and equipment designed to process company data in the form of information. The purpose of this study is to analyze the application of a payroll accounting system to internal control at PT Sarana Sulut Ventura with descriptive qualitative method. This study finds that the documents and records are good, but the functions, procedures, and internal control are not good. This result indicates that the payroll accounting system applied at PT Sarana Sulut Ventura has not been good and is not in accordance with generally accepted theories. This has an impact on the internal control system applied at PT Sarana Sulut Ventura, which is also inadequate because it does not meet the components of good internal control.
\end{abstract}

Keywords: payroll accounting system; internal control

\section{PENDAHULUAN}

Karyawan memiliki peran yang sangat penting dalam suatu aktivitas perusahaan. Kinerja sumber daya manusia atau karyawan juga didukung dengan sistem akuntansi pada perusahaan. Dalam memberikan kontribusi kepada perusahaan, maka karyawan akan mendapat kompensasi sebagai bentuk penghargaan atas hasil kerjanya. Kompensasi yang diterima karyawan dari perusahaan berupa gaji dan upah. Gaji dan upah termasuk biaya tenaga kerja yang sangat memerlukan ketelitian dalam penghitungan, pencatatan dan pembayarannya.

Sistem akuntansi penggajian dan pengupahan mencakup berbagai hal terkait dengan masalah gaji dan upah, tidak hanya mencakup mengenai besaran gaji dan upah yang harus dibayarkan oleh perusahaan tetapi juga mencakup proses menghitung seperti dari pencatatan waktu hingga gaji tersebut diberikan kepada pihak yang menerima gaji tersebut. Permasalahan yang sering terjadi dalam sistem dan prosedur penggajian dan pengupahan seperti yang terjadi pada pembayaran untuk karyawan fiktif, pembayaran yang diotorisasi dengan tidak baik, perhitungan yang salah dan transaksi yang tidak diklasifikasikan dengan tepat (Messier et al., 2014:13).

PT Sarana Sulut Ventura adalah Perusahaan Modal Ventura Daerah (PMVD) yang didirikan tahun 1996 dan mendapat izin operasi dari Departemen Keuangan Republik Indonesia. PT Sarana Sulut Ventura masih menggunakan daftar hadir manual dengan memasukkan kartu hadir ke dalam mesin waktu. Absen tersebut belum terkomputerisasi sehingga dapat terjadi kesalahan pada saat melakukan rekapan daftar hadir karyawan. Perusahaan yang memiliki sistem akuntansi penggajian dan pengupahan yang baik dan tepat akan lebih mudah bagi pemimpin untuk menetapkan besaran gaji karyawan, serta akan lebih mudah bagi perusahaan untuk mengawasi sehingga informasi data yang diperoleh akan jauh lebih akurat untuk digunakan dalam pengambilan keputusan. Pengawasan yang baik dalam sistem akuntansi penggajian dan pengupahan tentunya juga merupakan faktor pendukung sistem pengendalian intern bagi perusahaan. 


\section{TINJAUAN PUSTAKA}

Sistem akuntansi. Mulyadi (2016:3) menyatakan bahwa sistem akuntansi adalah organisasi formulir, catatan, dan laporan yang dikoordinasi sedemikian rupa untuk menghasilkan informasi keuangan yang diperlukan oleh manajemen untuk pengelolaan. Bodnar dan Hopwood (2014:3) menyatakan bahwa sistem informasi akuntansi merupakan kumpulan sumber daya, seperti manusia dan peralatan, yang dirancang untuk mengubah data keuangan dan data lainnya menjadi informasi. Romney dan Steinbart (2015:3) menyatakan bahwa sistem informasi akuntansi adalah sumber daya manusia dan modal dalam organisasi yang bertanggung jawab untuk persiapan informasi keuangan dan informasi yang diperoleh dari mengumpulkan dan memproses berbagai transaksi perusahaan. Krismiaji (2015:15) menyatakan bahwa sistem informasi adalah cara yang diorganisasikan untuk mengumpulkan, memasukkan, dan mengolah serta menyimpan data, dan cara yang diorganisasi untuk menyimpan, mengelola, mengendalikan, dan melaporkan informasi sedemikian rupa, sehingga sebuah organisasi dapat mencapai tujuan yang telah ditetapkan. Weygandt et al. (2019:5) menyatakan bahwa umumnya suatu sistem akuntansi dikembangkan dalam 4 (empat) tahap, yaitu: (a) analisis; (b) perancangan; (c) implementasi/penerapan; dan (d) tindaklanjut. Baridwan (2010:4) menyatakan bahwa sistem akuntansi adalah formulir, catatan-catatan, prosedur-prosedur dan alat untuk mengolah data mengenai usaha suatu kesatuan ekonomis dan tujuan untuk menghasilkan umpan balik dalam bentuk laporanlaporan yang diperlukan oleh manajemen untuk mengawasi usahanya, dan bagi pihak yang berkepentingan seperti pemegang saham, kreditor dan lembaga pemerintahan untuk menilai hasil operasi.

Sistem akuntansi penggajian. Mulyadi (2016:309) menyatakan bahwa sistem akuntansi penggajian adalah sistem pembayaran atas penyerahan jasa yang dilakukan oleh karyawan yang mempunyai jenjang jabatan pada suatu perusahaan. Menurut Sujarweni (2015:127), sistem penggajian dan pengupahan adalah sistem yang digunakan oleh perusahaan untuk memberi upah dan gaji kepada karyawannya atas jasa yang diberikan.

Fungsi terkait dengan sistem akuntansi penggajian. Menurut Halim dan Budisantoso (2014:135), fungsi yang terkait dengan sistem akuntansi penggajian dan pengupahan adalah sebagai berikut:

1. Fungsi penerimaan karyawan baru. Fungsi ini bertugas untuk menentukan layak tidaknya seseorang diterima sebagai karyawan baru perusahaan. Fungsi ini harus mengecek kelayakan tersebut sesuai dengan aturan yang ditetapkan manajemen.

2. Fungsi otorisasi pengubahan gaji dan upah. Fungsi ini dipegang oleh departemen personalia. Supervisor, karyawan atau atasan karyawan tersebut dapat mengusulkan perubahan tarif gaji dan upah atau kenaikan jabatan.

3. Fungsi pelaksana absensi dan data waktu kerja. Fungsi ini sangat penting dalam audit gaji dan upah karena secara langsung memengaruhi biaya gaji dan upah suatu periode. Pada perusahaan besar, fungsi ini dipegang oleh suatu departemen pencatatan waktu (timekeeping).

4. Fungsi pelaksana gaji dan upah. Fungsi ini dipegang oleh departemen gaji dan upah serta EDP (pada sistem komputer). Departemen ini mengolah data jam kerja karyawan untuk menentukan (menghitung) gaji dan upah setiap karyawan sesuai tarif yang ditentukan.

5. Fungsi pencatatan gaji dan upah. Fungsi ini dipegang oleh bagian akuntansi. Pengendalian yang dilakukan fungsi ini berupa pencatatan biaya gaji dan upah berdasarkan cek gaji dan upah yang didukung dengan voucher gaji dan upah.

6. Fungsi pembayar gaji dan upah. Bendahara/kasir kantor biasanya memegang fungsi ini. Bendahara kantor menerima cek register voucher dan cek gaji dan upah.

7. Fungsi penyiapan dan pembayaran pajak penghasilan karyawan. Sesuai dengan UndangUndang Pajak Penghasilan, perusahaan harus memotong pajak berupa PPh pasal 21 atas 
gaji dan upah karyawannya apabila penghasilan karyawan sudah berada di atas Penghasilan Tidak Kena Pajak.

Dokumen dan catatan yang digunakan dalam sistem akuntansi penggajian. Menurut Arens et al. (2015:248), dokumen dan catatan yang digunakan dalam sistem akuntansi penggajian dan pengupahan adalah: (1) dokumen dan catatan yang digunakan dalam fungsi bisnis sumber daya manusia dan kesempatan kerja; (2) dokumen dan catatan yang digunakan dalam fungsi bisnis pencatatan waktu dan persiapan penggajian; (3) dokumen dan catatan yang digunakan dalam fungsi bisnis pembayaran gaji; dan (4) dokumen dan catatan yang digunakan dalam fungsi penyusunan SPT pajak gaji dan pembayaran pajak.

Jaringan prosedur yang membentuk sistem akuntansi penggajian. Mulyadi (2016:385) menjelaskan bahwa sistem akuntansi penggajian terdiri dari jaringan prosedur berikut ini: (1) prosedur pencatatan waktu hadir. Prosedur ini bertujuan untuk mencatat waktu hadir karyawan. Pencatatan waktu hadir ini diselenggarakan oleh fungsi pencatat waktu dengan menggunakan daftar hadir pada pintu masuk kantor administrasi; (2) prosedur pembuatan daftar gaji. Dalam perusahaan manufaktur yang produksinya berdasarkan pesanan, pencatatan waktu kerja diperlukan bagi karyawan yang bekerja di fungsi produksi untuk keperluan distribusi biaya upah karyawan kepada produk atau pesanan yang menikmati jasa karyawan tersebut; (3) prosedur distribusi biaya gaji. Dalam prosedur ini, biaya tenaga kerja didistribusikan kepada departemen yang menikmati manfaat tenaga kerja. Distribusi tenaga kerja ini dimaksudkan untuk pengendalian biaya dan perhitungan harga pokok produk; (4) prosedur pembuatan bukti kas keluar. Prosedur ini melibatkan fungsi akuntansi dan keuangan. Fungsi akuntansi membuat perintah pengeluaran kas kepada fungsi keuangan untuk menulis cek guna pembayaran gaji dan upah; dan (5) prosedur pembayaran gaji.

Pengendalian intern. Arens et al. (2015:24) menyatakan bahwa pengendalian internal (internal control) merupakan proses yang dirancang untuk memberikan keyakinan yang memadai terkait dengan pencapaian tujuan manajemen dalam beberapa kategori, yaitu: keandalan dalam laporan keuangan, efektivitas dan efisiensi operasional perusahaan, dan kepatuhan terhadap hukum dan peraturan. Menurut Harnanto (2019:240), sistem pengendalian internal meliputi berbagai teknik, prosedur dan praktik yang diterapkan perusahaan untuk mendapatkan suatu sistem informasi akuntansi yang efisien juga dapat diandalkan, sehingga manajemen mendapatkan bantuan dalam hal merencanakan dan mengendalikan kegiatan usaha dan menjaga keamanan aset perusahaan. Herry $(2015: 159)$ menyebutkan bahwa pengertian pengendalian internal adalah seperangkat kebijakan dan prosedur untuk melindungi kekayaan perusahaan dari segala bentuk tindakan penyalahgunaan, menjamin terjadinya informasi akuntansi perusahaan yang akurat, serta memastikan bahwa semua ketentuan hukum atau undang-undang serta kebijakan manajemen telah dipatuhi atau dijalankan sebagaimana mestinya oleh seluruh karyawan perusahaan. Menurut Sujarweni (2019:69), pengendalian internal adalah serangkaian proses dalam organisasi. Supriyono (2016:147) menyatakan bahwa pengendalian internal meliputi rencana organisasi dan seluruh metode serta ukuran yang dikoordinasi, yang digunakan dalam suatu bisnis untuk melindungi aset-asetnya, memeriksa akurasi dan keandalan data akuntansi, mempromosikan efisiensi operasional, dan mendorong ketaatan pada kebijakan manajerial.

Komponen pengendalian internal. Menurut Committee of Sponsoring Organization of The Treadway Commissions (COSO) dalam Graham (2007) adalah:

1. Lingkungan pengendalian (control environment). Lingkungan pengendalian terdiri dari tindakan, kebijakan dan prosedur yang menggambarkan pandangan top management, direktur, dan pemilik entitas secara keseluruhan mengenai pengendalian internal dan pentingnya bagi entitas. Lingkungan atau budaya yang harus diciptakan manajemen untuk menghindari terjadinya kecurangan laporan keuangan atau kesalahan lain meliputi: (a) model operasi dan filosofi manajemen; (b) nilai etika dan integritas; (c) komitmen 
terhadap kompetensi; (d) dewan direksi atau komite audit; (e) struktur organisasi; (f) pembagian kewenangan dan tanggung jawab; dan (g) praktik dan kebijakan sumber daya manusia.

2. Penilaian risiko (risk assessment). Penilaian risiko untuk pelaporan keuangan yaitu identifikasi dan analisis manajemen mengenai risiko yang relevan dengan persiapan laporan keuangan yang sesuai dengan prinsip yang diterima secara umum. Proses yang dijalankan meliputi: (a) mengidentifikasi faktor yang mempengaruhi risiko; (b) mengukur tingkat signifikansi risiko dan kemungkinan terjadinya; dan (c) menentukan tindakan yang diperlukan untuk mengelola risiko.

3. Aktivitas pengendalian (control activities). Aktivitas pengendalian merupakan kebijakan dan prosedur yang membantu memastikan bahwa tindakan yang diperlukan telah dilakukan untuk menangani risiko dalam pencapaian tujuan perusahaan. Aktivitas ini meliputi: (a) pemisahan tugas yang memadai; (b) otorisasi yang tepat atas transaksi dan aktivitas; (c) dokumen dan catatan yang memadai; (d) pengendalian fisik atas harta dan catatan; dan (e) pemeriksaan kinerja dan independen.

4. Informasi dan komunikasi (information and communication). Tujuan dari sistem informasi dan komunikasi yaitu untuk mengawali, mencatat, memproses, dan melaporkan transaksi perusahaan serta untuk menjaga akuntabilitas harta yang terkait. Pertimbangan utama dalam komponen ini meliputi: (a) mengidentifikasi dan memperoleh informasi yang berhubungan dengan laporan keuangan; dan (b) mengkomunikasikan informasi yang relevan dalam format yang sesuai.

5. Pengawasan (monitoring). Aktivitas pengawasan mencakup penilaian yang berkelanjutan atau periodik terhadap kualitas kinerja pengendalian internal oleh manajemen untuk menentukan apakah pengendalian telah berjalan dengan baik dan telah dimodifikasi sesuai perubahan kondisi.

\section{METODE PENELITIAN}

Jenis penelitian yang digunakan adalah kualitatif dengan menggunakan pendekatan deskriptif. Menurut Sugiyono (2017:2), penelitian dilakukan pada kondisi yang alamiah langsung ke sumber data, atau diperoleh dari rekaman, pengamatan, atau bahan tertulis dalam bentuk uraian. Penelitian ini menganalisis sistem akuntansi penggajian dalam rangka meningkatkan pengendalian intern pada PT Sarana Sulut Ventura. Penelitian ini dilakukan di PT Sarana Sulut Ventura yang beralamat di Kompleks Pasar Segar Paal Dua Ruko RC 17, Jl.Yos Sudarso, Kota Manado-Sulawesi Utara, dengan waktu penelitian dimulai sejak bulan Januari-Mei 2020.

Jenis data penelitian yaitu data kuantitatif dan data kualitatif, dimana: (a) data kuantitatif adalah data yang diukur dalam suatu skala numerik (angka); dan (b) data kualitatif adalah data yang tidak dapat diukur dalam skala numerik. Jenis data penelitian yang digunakan yaitu data kualitatif. Data kualitatif dari PT Sarana Sulut Ventura dalam penelitian ini berupa: (a) hasil wawancara dengan pimpinan mengenai sistem akuntansi penggajian dalam rangka meningkatkan pengendalian intern; (b) sejarah, tugas pokok dan fungsi; (c) visi dan misi; (d) struktur organisasi; dan (e) standar operasional prosedur penggajian.

\section{HASIL PENELITIAN DAN PEMBAHASAN}

\subsection{Hasil penelitian}

Fungsi yang terkait dalam sistem akuntansi penggajian. Fungsi yang terdapat pada PT Sarana Sulut Ventura adalah:

a. Fungsi pelaksana absensi dan data waktu kerja. Fungsi ini dikelola oleh bagian keuangan. Fungsi ini memiliki wewenang untuk menyiapkan perjanjian kerja dengan 
karyawan baru, serta menyiapkan rekapitulasi absensi dan daftar hadir karyawan. Data ini yang akan digunakan sebagai pembuatan daftar gaji.

b. Fungsi pelaksana gaji. Fungsi ini bertugas untuk membuat daftar gaji beserta rincian hak karyawan dan berbagai potongan (BPJS TK, pajak penghasilan, dan pinjaman karyawan) yang menjadi beban setiap karyawan yang dikelola oleh bagian keuangan.

c. Fungsi pencatat gaji. Fungsi ini bertugas untuk membuat dan mencatat segala hal menyangkut gaji karyawan PT Sarana Sulut Ventura. Fungsi ini juga bertugas untuk mengecek kembali daftar gaji yang dibuat bagian akuntansi.

d. Fungsi pembayar gaji. Fungsi ini bertugas untuk membuat rincian daftar gaji karyawan perusahaan, mentransfer uang gaji lewat bank serta membuat slip gaji yang nantinya akan dibagikan kepada karyawan.

Dokumen yang digunakan dalam sistem akuntansi penggajian. Dokumen yang dipakai PT Sarana Sulut Ventura adalah:

a. Kartu kehadiran/absensi. Dokumen kartu kehadiran/absensi ini dipakai untuk mencatat waktu masuk dan keluar kantor setiap karyawan, kemudian setiap satu bulan direkap oleh bagian keuangan.

b. Daftar gaji karyawan. Dokumen ini berisi rincian gaji pokok, honorarium, tunjangan makan, tunjangan transpor dan tunjangan komunikasi, dikurangi iuran BPJS TK, pinjaman karyawan, bunga pinjaman dan berdasarkan rekapitulasi kehadiran setiap karyawan PT Sarana Sulut Ventura.

c. Slip gaji. Dokumen ini berisi rincian gaji yang akan diterima setiap karyawan. Slip gaji diberikan bersama gaji yang diterima oleh setiap karyawan PT Sarana Sulut Ventura.

Catatan yang dipakai dalam sistem akuntansi penggajian. Catatan yang dipakai oleh PT Sarana Sulut Ventura adalah:

a. Jurnal umum. Jurnal umum merupakan catatan akuntansi yang digunakan untuk mencatat transaksi keuangan perusahaan, dalam hal ini mencatat pembayaran gaji untuk setiap karyawan PT Sarana Sulut Ventura.

b. Memo internal. Memo internal merupakan surat pernyataan yang dibuat oleh bagian akuntansi secara resmi untuk diberikan kepada direktur untuk pengajuan pencairan dana pembayaran gaji karyawan PT Sarana Sulut Ventura.

Prosedur dalam sistem penggajian pada PT Sarana Sulut Ventura. Prosedur sistem akuntansi penggajian pada PT Sarana Sulut Ventura sebagai berikut:

a. Prosedur pencatatan daftar hadir. Prosedur pencatatan daftar hadir karyawan dimulai dari karyawan memasukkan kartu waktu ke dalam mesin pencatat waktu hadir pada saat masuk dan keluar kantor.

b. Prosedur pembuatan daftar gaji. Prosedur ini dikelola oleh bagian keuangan yaitu membuat daftar gaji karyawan dalam rangka pembayaran gaji. Daftar gaji berisi rincian gaji pokok, honorarium, tunjangan makan, tunjangan transpor dan tunjangan komunikasi, dikurangi iuran BPJS TK, pinjaman karyawan, bunga pinjaman dan berdasarkan rekapitulasi kehadiran setiap karyawan PT Sarana Sulut Ventura.

c. Prosedur pembayaran gaji. Prosedur pembayaran gaji karyawan pada dasarnya sama dengan perusahaan pada umumnya, yaitu pembayaran gaji yang diberikan secara utuh berdasarkan tingkat jabatan, absensi dan waktu lembur karyawan.

Pengendalian intern terhadap sistem akuntansi penggajian pada PT Sarana Sulut Ventura. Pengendalian intern terhadap sistem akuntansi penggajian pada PT Sarana Sulut Ventura sebagai berikut:

a. Organisasi.

1. Fungsi pencatatan daftar hadir yang dikelola oleh bagian keuangan/kasir.

2. Fungsi pembuat daftar gaji yang dikelola oleh bagian keuangan/kasir.

b. Sistem Otorisasi. 
1. Kartu kehadiran/absensi diotorisasi oleh fungsi keuangan/kasir.

2. Keputusan lembur diotorisasi langsung oleh pemimpin.

3. Daftar gaji diotorisasi oleh fungsi keuangan/kasir.

4. Bukti kas keluar untuk pembayaran gaji diotorisasi oleh fungsi akuntansi.

5. Memo internal untuk pengajuan pencairan dana pembayaran gaji karyawan dibuat oleh fungsi akuntansi.

c. Prosedur pencatatan. Perubahan gaji dan pembayaran gaji dibuat oleh bagian akuntansi.

d. Praktik yang sehat.

1. Setelah bagian keuangan bertanggung jawab atas rekapitulasi kartu kehadiran dan melakukan pengecekan kembali rekapitulasi kehadiran karyawan sebelum dipakai sebagai dasar penggajian.

2. Daftar gaji diperiksa kembali kebenaran dan ketelitian perhitungannya oleh bagian akuntansi.

3. Semua catatan menyangkut penggajian dibuat dan disimpan oleh bagian akuntansi.

\subsection{Pembahasan}

Fungsi pelaksana absensi dan data waktu kerja seharusnya dikelola oleh bagian personalia tetapi bagian personalia pada perusahaan hanya bertugas untuk menyeleksi calon karyawan dan menentukan penempatan karyawan. Hal ini membuat bagian keuangan yang secara khusus menangani pengecekan absen sekaligus melakukan rekapitulasi absen karyawan. Setelah rekapitulasi absen karyawan dibuat maka rekapitulasi absen karyawan diserahkan ke fungsi pelaksana gaji. Fungsi pelaksana gaji ini dilakukan oleh bagian keuangan yaitu membuat rincian gaji karyawan yang akan diterima dan juga sekaligus melakukan pembayaran gaji karyawan. Rincian gaji karyawan ini kemudian diserahkan ke fungsi pencatat gaji. Fungsi pencatat gaji ini telah dijalankan dengan baik oleh bagian akuntansi. Fungsi ini menerima rekapan daftar gaji dari fungsi pelaksana gaji dan kemudian mencatat setiap transaksi penggajian ke dalam jurnal umum. Fungsi pembayar gaji ini dikelola oleh bagian keuangan. Gaji setiap karyawan dibayarkan melalu transfer ke rekening setiap karyawan perusahaan. Fungsi ini sudah berjalan dengan baik tetapi akan lebih baik jika slip gaji dan bukti transfer gaji diberikan kepada masing-masing karyawan. Fungsi ini juga seharusnya membuat slip gaji dan lampiran bukti transfer gaji, dimana pada saat karyawan menandatangani daftar gaji/tanda terima gaji maka karyawan akan diberikan slip gaji dan bukti transfer gaji oleh fungsi pembayar gaji.

Kartu kehadiran/absensi ini sudah baik karena menginformasikan kehadiran setiap karyawan, apabila ada karyawan yang mempunyai tugas luar atau keluar kantor untuk makan siang maka karyawan tersebut wajib mengisi buku kontrol karyawan yang telah disiapkan perusahaan. Tetapi kartu kehadiran/absensi ini perlu diawasi dengan baik oleh bagian personalia agar informasi kehadiran setiap karyawan akurat dan dapat dipercaya. Daftar gaji ini sudah dapat dikatakan baik karena rincian gaji pokok, honorarium, tunjangan makan, tunjangan transpor dan tunjangan komunikasi, dikurangi iuran BPJS TK, pinjaman karyawan, bunga pinjaman dan berdasarkan rekapitulasi kehadiran setiap karyawan. Slip gaji yang digunakan perusahaan sudah baik, karena menginformasikan rincian gaji yang akan diterima setiap karyawan, tetapi slip gaji ini belum diserahkan kepada masing-masing karyawan perusahaan. Slip gaji ini harus diserahkan bersama dengan bukti transfer ke bank pada saat penandatanganan daftar gaji. Hasil penelitian menunjukkan bahwa catatan akuntansi yang digunakan adalah jurnal dan buku besar. Catatan akuntansi yang digunakan sudah baik, terlihat dengan adanya jurnal dan buku besar untuk mencatat transaksi terkait pembayaran gaji karyawan. Untuk setiap jurnal diberikan keterangan jurnal sehingga pengguna dengan mudah mendapat informasi.

Prosedur pencatatan daftar hadir pada perusahaan belum bisa dikatakan baik, hal ini dapat dilihat dari daftar hadir yang masih manual dan tidak ada pengawasan yang dilakukan 
oleh bagian yang bertugas untuk mengawasi daftar hadir. Seharusnya ada bagian personalia yang melakukan pengawasan terhadap daftar hadir karyawan. Prosedur pembuatan daftar gaji pada PT Sarana Sulut Ventura sudah dapat dikatakan baik, di mana di dalam daftar gaji sudah mencakup rincian gaji pokok, honorarium, tunjangan makan, tunjangan transpor dan tunjangan komunikasi, dikurangi iuran BPJS TK, pinjaman karyawan, bunga pinjaman dan berdasarkan rekapitulasi kehadiran setiap karyawan. Proses pembayaran gaji yang dilakukan perusahaan sebenarnya sudah bagus karena melalui transfer bank bukan pembayaran secara tunai. Proses pembayaran gaji ini sebaiknya harus dilanjutkan dengan pemberian tindisan bukti transfer pada saat karyawaan menandatangani daftar gaji.

Lingkungan pengendalian. PT Sarana Sulut Ventura telah mengkomunikasikan kepada semua karyawan akan tanggung jawab setiap karyawan dan ada kode etik perusahaan secara tertulis, tetapi masih ada karyawan yang belum sepenuhnya melakukan tanggung jawab dengan baik. PT Sarana Sulut Ventura merekrut karyawan berdasarkan pengetahuan dan keterampilan terkait dengan pekerjaan yang akan dikerjakan dengan latar belakang Sarjana atau sederajat. PT Sarana Sulut Ventura juga mewajibkan karyawan untuk mengikuti berbagai pelatihan yang disediakan oleh perusahaan agar dapat menciptakan karyawan yang kompeten. Lingkungan pengendalian pada PT Sarana Sulut Ventura ini sudah cukup baik, karena ada hal ini dapat dilihat dari tingginya integritas dan nilai etika pada perusahaan, adanya pengembangan kemampuan bagi karyawan dengan cara pembinaan/pelatihan yang disediakan oleh perusahaan, adanya filosofi manajemen yang diterapkan untuk mencapai tujuan perusahaan, adanya struktur organisasi, adanya kebijakan mengenai sumber daya manusia yaitu pelatihan bagi karyawan.

Penaksiran risiko. Faktor utama dari PT Sarana Sulut Ventura yang mempengaruhi risiko terhadap penggajian yaitu terletak pada absen menggunakan kartu waktu (clock card) yang bisa dikatakan masih manual dimana data-data dalam absen tersebut masih akan direkap secara manual. Terkait faktor absen yang masih menggunakan kartu waktu (clock card) pada PT Sarana Sulut Ventura ini dapat menyebabkan adanya penyalahgunaan absen yang dilakukan oleh karyawan perusahaan seperti adanya karyawan yang meminta tolong karyawan lain untuk mengisikan kartu waktu ke dalam mesin pencatat waktu atau bisa saja karyawan mengisikan kartu waktu ke dalam mesin pencatat waktu secara berulang kali sehingga waktu yang tertera tidak dapat terbaca oleh fungsi pencatat daftar hadir. Hal ini tentu saja dapat mengganggu proses penggajian karyawan, terutama dari segi penentuan gaji setiap karyawan perusahaan. Berdasarkan data penelitian, maka penaksiran risiko pada PT Sarana Sulut Ventura ini belum dapat dikatakan baik. Hal ini dibuktikan dengan absen yang masih menggunakan kartu waktu (clock card) karena dengan penggunaan kartu waktu memungkinkan karyawan meminta karyawan lain untuk memasukkan kartu waktu tersebut. Rekapitulasi daftar hadir yang masih manual belum terkomputerisasi, ini dapat menyebabkan ada salah rekapitulasi daftar hadir setiap karyawan.

Aktivitas pengendalian. Dalam kegiatan yang dilakukan perusahaan khususnya dalam proses penggajian pemisahan tugas antar karyawan ini belum diterapkan secara baik. Hal ini dapat dilihat dari adanya tugas rangkap oleh bagian keuangan yang melakukan rekapitulasi daftar hadir sekaligus membuat daftar gaji karyawan. Dengan adanya rangkap fungsi maka pengendalian intern PT Sarana Sulut Ventura telah menerapkan sistem otorisasi yang dapat dikatakan baik, hal ini dapat dilihat dari keputusan lembur karyawan diotorisasi langsung oleh pemimpin perusahaan, daftar gaji diotorisasi oleh fungsi keuangan/kasir serta otorisasi yang dilakukan oleh fungsi akuntansi terkait dengan bukti kas keluar. Untuk aktivitas pengendalian khususnya untuk pemisahan tugas yang belum baik pada perusahaan, hal ini akan mengakibatkan sistem pengendalian intern perusahaan akan terganggu.

Informasi dan komunikasi. PT Sarana Sulut Ventura memiliki data dan informasi mengenai gaji karyawan perusahaan ini diolah baik dengan menggunakan komputer sehingga 
meminimalkan kesalahan dalam proses mengolah data. PT Sarana Sulut Ventura menerapkan adanya pengarahan (briefing) kepada setiap karyawan saat masuk kerja. Hal ini dilakukan perusahaan agar terjadi komunikasi yang baik antar atasan dan karyawan perusahaan. Berdasarkan data penelitian, maka dapat dikatakan bahwa informasi dan komunikasi pada PT Sarana Sulut Ventura ini sudah cukup baik, hal ini dilihat dari pengolahan gaji dengan menggunakan komputer. Perhitungan gaji diolah dengan microsoft excel dan semua kewajiban dicatat dalam jumlah yang tepat sehingga mengurangi kesalahan perhitungan dan input data. Selain pengolahan gaji menggunakan komputer, perusahaan juga selalu melakukan pengarahan kepada setiap karyawan.

Pengawasan. Siwu dan Poputra (2017) menjelaskan bahwa pengawasan dicapai melalui aktivitas yang terus-menerus (on going monitoring), evaluasi yang terpisah (separate evaluation), atau kombinasi keduanya. Aktivitas yang terus-menerus (on going monitoring) mencakup aktivitas supervisi manajemen dan tindakan lain yang dapat dilakukan untuk memastikan bahwa proses pengendalian internal secara berkelanjutan berjalan dengan efektif. Evaluasi yang terpisah (separate evaluation) adalah penilaian secara periodik atas kinerja organisasi dengan standar pengukuran yang sudah disepakati sebelumnya. Hasil analisis data menunjukkan bahwa pengawasan pada PT Sarana Sulut Ventura ini belum cukup baik, dilihat dari kurangnya pengawasan yang dilakukan oleh perusahaan terhadap setiap karyawan. Perusahaan perlu mengawasi setiap karyawan agar karyawan dapat melakukan tugas dan fungsi sesuai dengan kebijakan yang berlaku.

\section{KESIMPULAN DAN SARAN}

\subsection{Kesimpulan}

Berdasarkan hasil penelitian, maka dapat disimpulkan bahwa sistem akuntansi penggajian yang diterapkan pada PT Sarana Sulut Ventura belum optimal dan belum sesuai dengan teori yang berlaku umum hal ini berdampak pada sistem pengendalian intern yang diterapkan pada PT Sarana Sulut Ventura juga kurang memadai karena belum memenuhi komponen pengendalian intern yang baik.

\subsection{Saran}

Berdasarkan hasil penelitian, maka PT Sarana Sulut Ventura sebaiknya melakukan pemisahan tugas antara bagian rekapitulasi absen dan pembuat daftar gaji dimana bagian personalia yang akan bertanggung jawab terhadap daftar hadir karyawan dan rekapitulasi daftar hadir sehingga bagian keuangan hanya bertanggung jawab terhadap pembuatan daftar gaji karyawan. Selain itu, sebaiknya PT Sarana Sulut Ventura melakukan perubahan absen dan daftar hadir manual dengan menggunakan daftar hadir sidik jari (fingerprint). Hal ini, dapat membantu perusahaan dalam merekap absen dan dapat meningkatkan kedisiplinan karyawan untuk meningkatkan pengendalian intern.

\section{DAFTAR PUSTAKA}

Arens, A. A., Randal, J. E., Mark, S. B., \& Jusuf, A. (2015). Auditing dan jasa assurance pendekatan terintegrasi, Edisi kedua. Jakarta: Salemba Empat.

Baridwan, Z. (2010). Sistem akuntansi penyusunan prosedur dana metode, Edisi 5. Yogyakarta: BPFE.

Bodnar, G, H., \& Hopwood, W. S. (2014). Sistem informasi akuntansi, Edisi kesembilan. Yogyakarta: Penerbit Andi.

Graham, L. (2007). Internal controls: Guidance for private, government, and nonprofit entities. Canada: John Willey and Sons. 
Halim, A., \& Budisantoso, T. (2014). Auditing 2: Dasar-dasar prosedur pengauditan laporan keuangan, Edisi keempat. Yogyakarta: UPP STIM YKPN.

Harnanto. (2019). Dasar-dasar akuntansi. Yogyakarta: Penerbit Andi.

Herry. (2015). Akuntansi Dasar 1 dan 2, Cetakan ketiga. Jakarta: PT Gramedia Widiasarana Indonesia.

Krismiaji. (2015). Sistem informasi akuntansi, Edisi keempat. Yogyakarta: UPP STIM YKPN.

Messier, W. F., Glover, S. M., \& Prawitt, D. F. (2014). Jasa audit dan assurance: Pendekatan sistematis, Edisi 8. Jakarta: Salemba Empat.

Mulyadi. (2016). Sistem akuntansi, Edisi keempat. Jakarta: Salemba Empat.

Romney, M. B., \& Steinbart, P. J. (2015). Sistem informasi akuntansi, Edisi 13. Jakarta: Salemba Empat.

Siwu, F. M., \& Poputra, A. T. (2017). Evaluasi penerapan sistem pengendalian internal atas penerimaan, pengembalian dan pelelangan barang jaminan pada PT Pegadaian $\begin{array}{llll}\text { (Persero). Jurnal } & \text { Accountability, }\end{array}$ https://doi.org/10.32400/ja.16022.6.1.2017.1-17

Sugiyono. (2017). Metode penelitian kuantitatif, kualitatif, dan R\&D. Bandung: Alfabeta CV.

Sujarweni, V. W. (2015). Sistem akuntansi, Cetakan Pertama. Yogyakarta: Pustaka Baru Press.

Sujarweni, V. W. (2019). Sistem akuntansi. Yogyakarta: Pustaka Baru Press.

Supriyono, R. A. (2016). Akuntansi keperilakuan. Cetakan Pertama. Yogyakarta: Gadjah Mada University Press.

Weygandt, J. J., Kimmel, P. D., \& Kieso, D. E. (2019). Pengantar akuntansi 1 berbasis IFRS. Jakarta: Salemba Empat. 